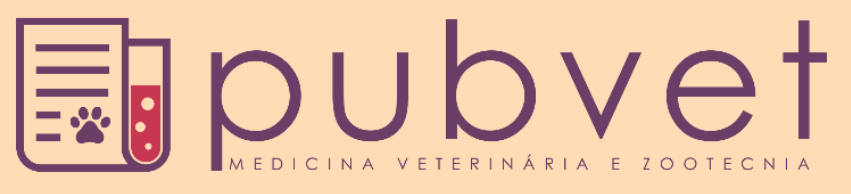

https://doi.org/10.31533/pubvet.v16n02a1035.1-6

\title{
Trochlear prosthesis and modified leveling osteotomy of the tibial plateau in dogs
}

\author{
Camila Francisca Batschke ${ }^{1 *(\mathbb{D})}$, Solimar Dutra da Silveira ${ }^{2}$ (D), Samara Koloda Cristino Malta ${ }^{3}$ (D), \\ Jaqueline Lunedo $^{3}\left(\mathbb{D}\right.$, Olicies da Cunha ${ }^{4}$, Eloy Henrique Pares Curuci ${ }^{5}$ (D)
}

'Médica Veterinária, Marechal Cândido Rondon, PR, Brasil.

${ }^{2}$ Médico Veterinário, Mestrando em Ciência Animal, Universidade Federal do Paraná (UFPR), Palotina - PR, Brasil.

${ }^{3}$ Médica Veterinária Residente do Departamento de Clínica Cirúrgica de Pequenos Animais, UFPR, Palotina - PR, Brasil.

${ }^{4}$ Docente do Departamento de Clínica Cirúrgica de Pequenos Animais, UFPR, Palotina - PR, Brasil.

${ }^{5}$ Médico veterinário, Serviço de Ortopedia e Traumatologia Veterinária Dr. Eloy Curuci. São Paulo SP, Brasil.

*Autor para correspondência, E-mail: mv.camilafb@gmail.com

\begin{abstract}
Medial patella luxation is a condition resulting from congenital bone deformities that in the long term may result in rupture of the cranial cruciate ligament. These orthopedic ailments are responsible for much of the pelvic limb claudication in dogs and degenerative joint disease. Claudication and joint pain are the main clinical manifestations, and the diagnosis is confirmed by orthopedic examination for both conditions. The simultaneous treatment of these diseases is a challenge for the surgeon. This study reports on the association of trochlear sulcus replacement with prosthesis with modified plateau leveling osteotomy for simultaneous treatment of grade III medial patellar dislocation and cranial cruciate ligament rupture in dogs.
\end{abstract}

Keywords: Dog, claudication, joint disease, pelvic limb, modified osteotomy

\section{Prótese troclear e osteotomia de nivelamento do platô tibial em cães}

\begin{abstract}
Resumo. A luxação de patela medial é uma afecção resultante de deformidades ósseas congênitas que a longo prazo pode resultar na ruptura do ligamento cruzado cranial. Essas enfermidades ortopédicas são responsáveis por grande parte das claudicações de membro pélvico dos cães e doença articular degenerativa. Claudicação e dor na articulação são as principais manifestações clínicas, sendo o diagnóstico confirmado por meio do exame ortopédico para as duas afecções. O tratamento simultâneo destas é um desafio para o cirurgião. Este estudo relata a associação de substituição do sulco troclear por prótese com osteotomia de nivelamento do platô modificada, para tratamento simultâneo de luxação de patela medial grau III e ruptura do ligamento cruzado cranial em cão.
\end{abstract}

Palavras-chave: Cão, claudicação, doença articular, membro pélvico, osteotomia modificada

\section{Introduction}

The anatomical deformities that precede medial patellar luxation (MPL) are present in dogs at birth and are responsible for the presentation of clinical manifestations during the course of the animal's development. Decreased inclination angle of the femoral neck and its relative retroversion precede MPL and are associated with other skeletal deformities, such as tibial tuberosity torsion and soft tissue displacement (DeCamp, 2015; Kowaleski et al., 2012; Von Pfeil \& DeCamp, 2009).

Limb elevation during gait and claudication are the main clinical manifestations of MPL, with claudication worsening as the resulting joint disease progresses or when the cranial cruciate ligament 
tears secondary to luxation, leading to an acute picture of the signs (DeCamp, 2015; Von Pfeil \& DeCamp, 2009). MPL diagnosis is based on clinical findings and the forms of treatment depend on the degree of luxation, bone deformities, and associated changes in the quadriceps muscle mechanism, which are found through imaging examinations. The treatment plan aims to realign the quadriceps mechanism and stabilize the patella in the trochlear sulcus (DeCamp, 2015; Flesher et al., 2019; Kowaleski et al., 2012).

The most commonly employed treatments for MPL correction include tracheoplasty, tibial tuberosity transposition, imbrication of the lateral retinaculum (DeCamp, 2015; Von Pfeil \& DeCamp, 2009), and trochlear sulcus replacement with prosthesis (Patellar Groove Replacement - PGR), the latter recently reported also for the treatment of severe osteoarthritis (Dokic et al., 2015) and iatrogenic trochlear injury (Kim et al., 2016).

It is estimated that $15 \%$ to $20 \%$ of knees with MPL develop RLCCr (DeCamp, 2015; Von Pfeil \& DeCamp, 2009), and this condition can also be of traumatic or degenerative origin, resulting from bone deformities, increased tibial plateau angle (TPA) inclination, immune-mediated atropathies, aging, and obesity (Buquera et al., 2004).

Clinical manifestations are similar to MPL, and patients exhibit sudden claudication, and knee elevation and flexion. The drawer test and positive tibial compression are clinical methods that enable RLCCr diagnosis. In association, radiographic examination is essential to assess TPA tilting and thus enable appropriate surgical planning for each patient (DeCamp, 2015; Flesher et al., 2019; Kowaleski et al., 2012).

As a simultaneous treatment for the aforementioned conditions, the Tibial Plateau Levelling Osteotomy Modified (TPLOM) promotes quadriceps realignment associated with tibial plateau leveling by translating the proximal segment of the tibia (Flesher et al., 2019; Langenbach et al., 1998; Langenbach \& Marcellin-Little, 2010).

This study aims to report the case of a dog diagnosed with grade III medial patellar dislocation and cranial cruciate ligament rupture, whose treatment was the simultaneous association of PGR and TPLOM techniques.

\section{Case report}

A one-and-a-half-year-old, castrated, non-breed, female dog weighing $10 \mathrm{~kg}$ with a history of left pelvic limb claudication received treatment for four months. During the orthopedic examination, the patient presented grade III MPL and positive tibial compression and drawer motion tests. The patient was referred for radiography of the femorotibiopatellar joint (Figures $1 \mathrm{~A}$ and $\underline{B}$ ) and computed tomography (CT) (Figure 2), which revealed a medially dislocated patella, flattening of the trochlear groove, hypoplastic medial trochlear ridge, TPA of $\pm 16^{\circ}$, and medial tibial torsion of the tibial tuberosity at $10^{\circ}$ in relation to the trochlear groove.

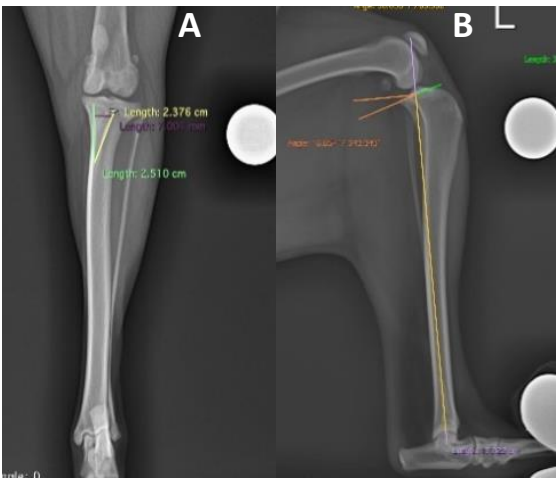

Figure 1. Preoperative radiographic image of the left femorotibiopatellar joint of a 10-year-old dog of undefined breed. A) Craniocaudal projection showing grade III MPL. B) Lateral projection showing tibial plateau angle.

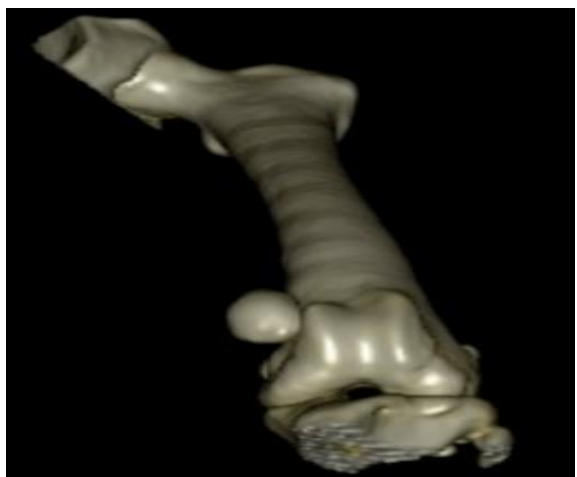

Figure 2. Tomographic image in three-dimensional reconstruction of the left femur of a 10-yearold dog of undefined breed, showing hypoplasia of the medial trochlear ridge and medial luxation of the patella. 
Considering the hypoplasia of the medial trochlear ridge, the permanently luxated patella, and the RLCCr, surgical treatment by the association of the PGR and TPLOM techniques was recommended.

After preoperative blood count, renal biochemistry (creatinine and urea), and hepatic biochemistry (albumin, alanine aminotransferase, alkaline phosphatase, and total proteins), the patient was premedicated with methadone $(0.2 \mathrm{mg} / \mathrm{kg})$ and dexmedetomidine $(0.5 \mathrm{mg} / \mathrm{kg})$. Anesthetic induction was performed with propofol $(4.0 \mathrm{mg} / \mathrm{kg})$, and maintenance was carried out with isoflurane in a semi-open inhalation circuit coupled to $100 \%$ oxygen. Antimicrobial prophylaxis was instituted with cephalothin $(30 \mathrm{mg} / \mathrm{kg})$.

The patient was positioned in dorsal decubitus with the affected limb aseptically prepared for surgery. The surgical access was performed on the medial side through the medial retinaculum, exposing the femorotibiopatellar joint.

Next, the patella was laterally luxated for adequate intra-articular exposure after joint inspection, confirming the RLCCr. The procedure was followed by ostectomy of the trochlea with a sagittal saw (Figure 3-A); the cut was made from the origin of the tendon of the long extensor muscle of the fingers to the proximal end of the trochlea. The preparation of the receptor bed of the base plate was finished with the help of a file (Figure. 3 - B).
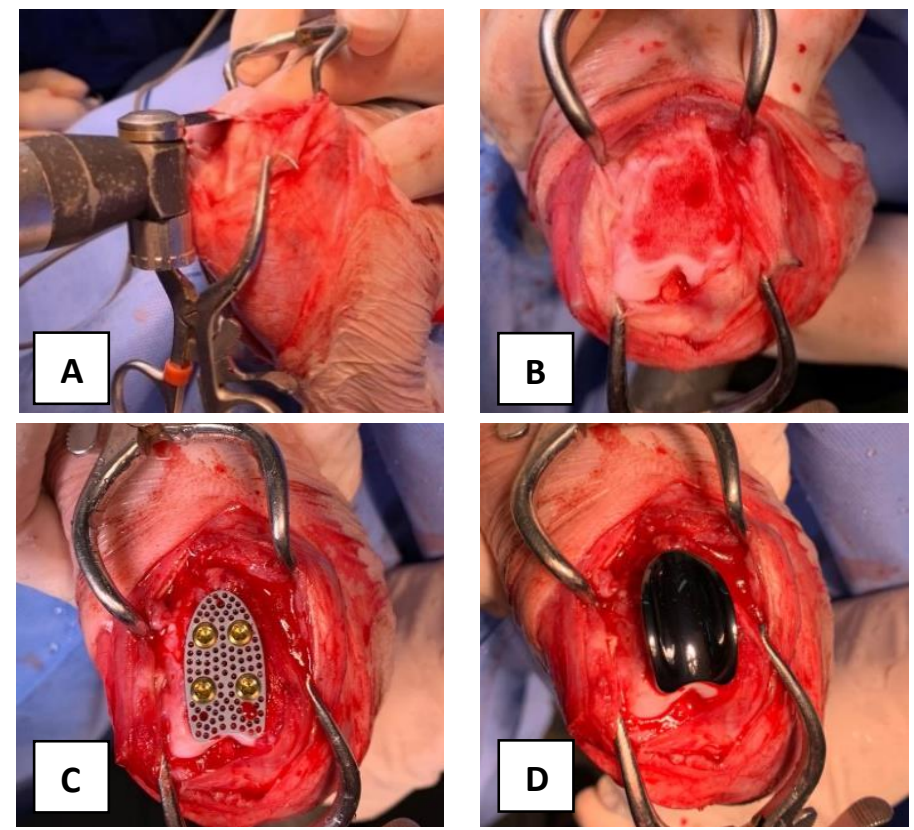

Figure 3. Technique of trochlear replacement with prosthesis. A) Ostectomy of the trochlea. B) Aspect of the trochlea after ostectomy. C) Base plate of trochlear prosthesis size 5 fixed to the trochlea. D) Final appearance of trochlear prosthesis replacement.

The prosthesis base plate was size 5 (Patellar Groove Replacement ${ }^{\circledR}$ - Kyon Vet, Switzerland). For its application, the base plate was temporarily fixed to the trochlear surface with a $25 \times 7$ mm hypodermic needle. Next, four $2.4 \mathrm{~mm}$ locked titanium cortical screws were applied (Figure 3 - C), then the trochlear prosthesis was positioned on the base plate by aligning the conical pins (Figure 3 - D) through pressure applied with a hammer, and finally the patella was positioned on the prosthesis.

After finishing the trochlear prosthesis fixation stage, the TPLOM was initiated with the release of the proximal portion of the tibia. To do so, the insertion of the sartorius muscle, as well as the origin of the popliteus muscle were incised. The tibial ostectomy was performed with a template, where the proximal tibial segment was rotated caudally to a $5^{\circ}$ TPA and medially translated until the subjective adjustment of the alignment of the quadriceps mechanism and the center of the new trochlear groove. To achieve this alignment, the medial translation of the proximal tibial segment was approximately 3 mm (Figure 4-A). 
After the final positioning of the proximal tibial fragment, it was temporarily fixed with $1.5 \mathrm{~mm}$ Kirschner wire inserted through the tibial tuberosity. The chosen plate was the $2.5 \mathrm{~mm}$ model V2005 (Fixin Intrauma, Italy), which was molded and applied with two screws in the proximal fragment and two screws in the distal fragment of the tibial osteotomy. The Kirschner wire was removed, followed by suturing of the joint capsule to the subcutaneous tissue and skin.

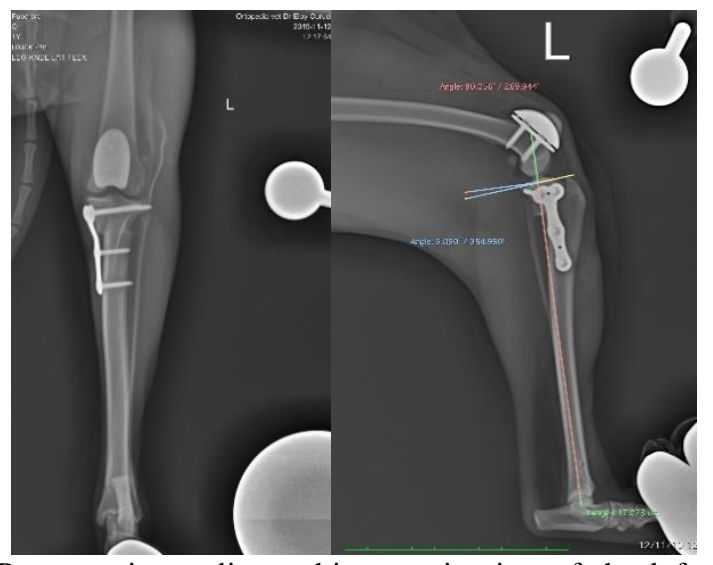

Figure 4. Preoperative radiographic examination of the left femorotibiopatellar joint of a non-breed, $10 \mathrm{~kg}$ dog. A) Craniocaudal projection showing PGR and TPLOM. B) Lateral projection showing TPA leveling at $\pm 5^{\circ}$ in relation to the femur.

The patient was discharged 12 hours after the procedure, with a prescription for analgesia and antibiotic therapy. Physiotherapy was started on the fifth postoperative day, and during clinical reevaluations, support of the affected limb was observed at seven days and complete ambulation and no signs of claudication at 30 days. Radiographs at 30 and 60 days postoperatively showed satisfactory bone healing and no instability of the implants.

\section{Discussion}

MPL is divided into grades I to IV, according to the bony deformities and the level of claudication of each patient (Singleton, 1969). The patient had a grade III MPL, where the patella remained permanently luxated even after manual repositioning, as a consequence of the shallow trochlear groove and underdeveloped medial trochlear ridge; there was also a $10^{\circ}$ medial deviation of the tibial tuberosity and rotation of the proximal end of the tibia on X-ray examination.

The patient exhibited sudden claudication and probable RLCCr at this time at one and a half years of age. It is described that older dogs with a higher degree of MPL are more likely to develop RLCCr (Campbell et al., 2010). Nevertheless, we reported the occurrence of RLCCr in a young animal, diverging from the literature; this may have occurred because MPL generates joint instability as a result of failure of the quadriceps muscle mechanism, resulting in pressure and distension of the cranial cruciate ligament and its rupture (DeCamp, 2015; Von Pfeil \& DeCamp, 2009).

The treatment is surgical for MPL starting at grade II, where bone and soft tissue reconstructions are indicated (DeCamp, 2015; Flesher et al., 2019). Traditional techniques for bone reconstructions include tracheoplasty and tibial tuberosity transposition (Bosio et al., 2017; DeCamp, 2015; Von Pfeil \& DeCamp, 2009; Wangdee et al., 2013). PGR is a new procedure already reported successfully for treating severe osteoarthritis (Dokic et al., 2015) and iatrogenic trochlear damage secondary to tracheoplasty (Kim et al., 2016); thus, the prosthesis was chosen as a result of the significant hypoplasia of the medial trochlear ridge present in the patient in question.

The choice of PGR in this study was based on the trochlear deformity and tearing of the trochlear groove, and this implant can be adjusted laterally or medially over the trochlear ostectomy for better alignment with the tibial tuberosity, in addition to providing superior patellar coverage and early return of limb function and can be used as a single or combined technique for better quadriceps alignment and RLCCr correction (Dokic et al., 2015), as was its combination with TPLOM. 
Dokic et al. (2015) reported complications of the PGR technique in 6/35 cases where there occurred osteoarthritis that was treated clinically, slippage of the patella to the distal end of the prosthesis, dislocation of the prosthesis, and recurrence of the dislocation, requiring surgical revision in the last three cases. No short- or medium-term postoperative complications have been found in the patient so far.

TPLOM adjusts the TPA by $5^{\circ}$, neutralizing tibial compression during gait, and aligns the quadriceps mechanism through medial translation of the tibia, simultaneously treating RLCCr and PLM (Flesher et al., 2019). In the present case, the medial translation of the tibia was $3 \mathrm{~mm}$. The trans-surgical displacement was performed gradually until aligning the quadriceps and patella assembly with the prosthetic trochlear groove, according to the literature consulted.

The TPLOM technique has already been combined with tracheoplasty and soft tissue reconstruction in large (Langenbach et al., 1998; Langenbach \& Marcellin-Little, 2010) and small dogs (Flesher et al., 2019), and showed a satisfactory result in association with PGR in this study.

Langenbach \& Marcellin-Little (2010) performed TPLOM on 13 knees of large dogs, and surgical reintervention was required in one patient with pain upon knee palpation at 239 days postoperatively; however, no complications were found in the case of this study.

Regarding the association of the two techniques performed in the study, there is a scarcity of data published in the literature. However, the patient in question presented a satisfactory evolution, with bone healing and implant stability. There was only a delay between the time of adequate return of weight bearing on the limb, which was solved without any intervention.

\section{Conclusion}

The combination of trochlear sulcus replacement and modified tibial plateau leveling osteotomy was effective for the simultaneous treatment of grade III medial patellar luxation associated with cranial cruciate ligament rupture. There were no complications from the association of the techniques in the postoperative period.

\section{References}

Bosio, F., Bufalari, A., Peirone, B., Petazzoni, M., \& Vezzoni, A. (2017). Prevalence, treatment and outcome of patellar luxation in dogs in Italy. Veterinary and Comparative Orthopaedics and Traumatology, 30(05), 364-370.

Buquera, L. E. C., Padilha Filho, J. G., \& Canola, J. C. (2004). Ruptura do ligamento cruzado cranial em cães: Revisão de literatura. Arquivos de Ciências Veterinárias e Zoologia Da UNIPAR, 7(1), 4347.

Campbell, C. A., Horstman, C. L., Mason, D. R., \& Evans, R. B. (2010). Severity of patellar luxation and frequency of concomitant cranial cruciate ligament rupture in dogs: 162 cases (2004-2007). Journal of the American Veterinary Medical Association, 236(8), 887-891.

DeCamp, C. E. (2015). Brinker, Piermattei and Flo's handbook of small animal orthopedics and fracture repair. Elsevier Health Sciences.

Dokic, Z., Lorinson, D., Weigel, J. P., \& Vezzoni, A. (2015). Patellar groove replacement in patellar luxation with severe femoro-patellar osteoarthritis. Veterinary and Comparative Orthopaedics and Traumatology, 28(02), 124-130.

Flesher, K., Beale, B. S., \& Hudson, C. C. (2019). Technique and outcome of a modified tibial plateau levelling osteotomy for treatment of concurrent medial patellar luxation and cranial cruciate ligament rupture in 76 stifles. Veterinary and Comparative Orthopaedics and Traumatology, 32(01), 26-32.

Kim, Y., Park, Y., Park, J., Jeong, S. M., \& Lee, H. (2016). Bilateral patellar groove replacement in a dog with iatrogenic trochlear groove damage. Journal of Veterinary Clinics, 33(5), 295-299.

Kowaleski, M. P., Boudrieau, R. J., \& Pozzi, A. (2012). Stifle joint. Veterinary Surgery: Small Animal, 1, 906-998. 
Langenbach, A, Anderson, M. A., Dambach, D. M., Sorenmo, K. U., \& Shofer, F. D. (1998). Extraskeletal osteosarcomas in dogs: a retrospective study of 169 cases (1986-1996). Journal of the American Animal Hospital Association, 34(2), 113-120.

Langenbach, Anke, \& Marcellin-Little, D. J. (2010). Management of concurrent patellar luxation and cranial cruciate ligament rupture using modified tibial plateau levelling. Journal of Small Animal Practice, 51(2), 97-103.

Singleton, W. B. (1969). The surgical correction of stifle deformities in the dog. Journal of Small Animal Practice, 10(2), 59-69.

Von Pfeil, D. J., \& DeCamp, C. E. (2009). The epiphyseal plate: physiology, anatomy, and trauma. Compendium Continuig Education for Veterinarians, 31(8), E1-11.

Wangdee, C., Theyse, L. F. H., Techakumphu, M., Soontornvipart, K., \& Hazewinkel, H. A. W. (2013). Evaluation of surgical treatment of medial patellar luxation in Pomeranian dogs. Veterinary and Comparative Orthopaedics and Traumatology, 26(06), 435-439.

Histórico do artigo:

Recebido: 21 de setembro de 2021

Aprovado: 24 de outubro de 2021

Disponível online: 23 de fevereiro de 2022
Licenciamento: Este artigo é publicado na modalidade Acesso Aberto sob a licença Creative Commons Atribuição 4.0 (CC-BY 4.0), a qual permite uso irrestrito, distribuição, reprodução em qualquer meio, desde que o autor e a fonte sejam devidamente creditados. 